\title{
Factors Affecting Investment in an English Literature Class at a Korean University
}

Kim, Jungyin', Qi, Lixia²

${ }^{1}$ First author, Professor, Jeonbuk National University, luvjanny07@gmail.com

${ }^{2}$ Corresponding author, Ph.D. Student, Jeonbuk National University, 610827532@qq.com

\section{Abstract}

This ethnographic study explored potential factors affecting students' investment in an English Literature class at a Korean public university. The study lasted four months altogether. Four students were selected as focal participants due to their differences in individual background, English language competence, and types of participation in the class. The data were mainly collected through class observations, semi-structured interviews, and class documents (e.g., the course syllabus and guidelines for learning literature). Drawing on Norton's theoretical terms of investment, power relations, identity, and positioning, as well as Lave and Wenger's theory of communities of practice, the study analyzed participants' individual differences, personal desires for the course, and forms of participation in classroom communities. Findings showed that students' investment in the English Literature class was interwoven with the following factors: 1) participants' individual differences, language competence, personalities influenced by their dominant cultures, and life trajectory; 2) the disjuncture between the course goal and students' personal desires for the class; and 3) inequitable power relations and differential identity positioning in the classroom communities. The study concluded that in English-based classes where students showed diverse cultural background and language competence, the instructor played a vital role in motivating students to invest in the class.

Key Words: community of practice, investment, identity positioning, power relations, English Literature class

This research was supported by "Research Base Construction Fund Support Program" funded by Jeonbuk National University in 2020
1. Introduction

2. Research Question

3. Theoretical Framework

4. Literature Review

5. Research Methods

6. Findings

7. Discussion

8. Conclusion and Implications 


\section{Introduction}

The Western Literature course has always been an essential constituent in the overall curricula offered for English majors. The general objective of the course aims to guide students to appreciate English literature, acquire multicultural and historical knowledge, and improve their English language skills and academic knowledge. However, in reality, not all students value such course and actively invest in the actual classroom activities. Therefore, the present researchers, through class observations and interviews with focal participants, conducted an ethnographic study to investigate students' investment in an English Literature class offered by the English department at a public university in South Korea (hereinafter, "Korea") based on Norton's theoretical terms of investment (Norton, 1995, 2010b), power relations (Norton, 1995, 2000, 2013), identity (Norton, 2000, 2013; Norton \& Toohey, 2011), and positioning (Norton, 2013; Norton \& Toohey, 2011), as well as Lave and Wenger's theory of communities of practice (CoP) (Lave \& Wenger, 1991; Wenger, 1998).

The remainder of this paper is organized as follows. First, the main research question is presented followed by the theoretical framework. Next, the setting, focal participants, data collection and analysis are presented. Thereafter, the findings and discussion are provided. Finally, pedagogical implications and limitations of the study are presented.

\section{Research Question}

The research question guiding this study was as follows: What factors influenced focal student participants' investment in the English Literature class of the English department at a Korean public university?

\section{Theoretical Framework}

To explore potential factors that may have hindered students' class investment, the researchers first employed Norton's construct of investment (Norton, 1995, 2010b) to analyze the connotation of this notion and its difference with motivation. Then, the study illustrated three related terms, namely power (Norton, 1995, 2000, 2013), identity (Norton, 2000, 2013; Norton \& Toohey, 2011), and positioning (Norton, 2013; Norton \& Toohey, 2011). Norton's notion of power adopts views of Foucault's micro-power (1980) and Bourdieu's symbolic power (1977), which inspired the researchers to explore participants' power differentials and their "right to speak" in the classroom groups, which in turn appeared to influence their class investment. Norton's perspective on identity positioning represented a shift in focus from the psycholinguistic to sociological and anthropological dimension in language learning (Norton, 2010a), which inspired the researchers to consider participants' multiple and shifting identities both in the classroom and their private and professional lives. Finally, considering that the main setting of this study was confined to the classroom and that different classroom groups existed as required by diverse course tasks, the researchers employed the framework of Community of Practice ( $\mathrm{CoP})$ as a context to explore the participants' class investment. Detailed illustrations on these concepts are provided as follows.

\subsection{The Theory of Investment}

Norton (1995) coined the notion of investment in her longitudinal case study about five immigrant women learners of English as a Second Language (ESL) in Canada. She defined investment as "the socially and historically constructed relationship of learners to the target language and their often ambivalent desire to learn and practice it" (Norton, 1995, p.17). Norton (2013) found that when learners invested in a second language, they expected to obtain some symbolic resources (e.g., language, education, 
and friendship) and material resources (e.g., capital goods, real estate, and money) as returns, which would promote their cultural capital and social power. The construct of investment was proposed to complement the notion of motivation in second language acquisition (SLA) research. Compared with motivation, investment captured a more complex, contradictory, dynamic relationships and multiple desires in learners to their social world (Norton, 1995, 2010a, 2010b, 2013; Norton \& Toohey, 2011). Researchers (e.g., Norton \& McKinney, 2011; Norton \& Toohey, 2011) have argued that a highly motivated language learner might still invest little and be positioned as an unmotivated and passive learner in a certain community. This contradiction will provide insights to the current study between the discrepancy seen between students' initial motivation in the class and their investments for the current English Literature class.

\subsection{The Theory of Power, Identity, and Positioning}

\subsubsection{Power Relations}

Following Foucault's (1980) micro-power theory, Norton defined power as "the socially constructed relations among individuals, institutions, and communities through which symbolic and material resources in a society are produced, distributed and validated" (Norton, 2013, p.47). She proposed that the notion of power should be included in theories of SLA; otherwise, the nature of participation in communicative events could not be defined and interpreted. In addition, Norton followed Bourdieu's view of symbolic power and supported expanding the notion of competence to include the awareness of the "right to speech," or "the power to impose reception" (Bourdieu, 1977, p.648). They agreed that second language speakers should equip themselves with the competence to be understood, believed, obeyed, and respected rather than only focus on linguistic rules of the target language (Bourdieu, 1977; Norton, 1995).

\subsubsection{Identity and Positioning}

Norton noted that identity was about "how a person understands his or her relationship to the world, how that relationship is constructed across time and space, and how the person understands possibilities for the future" (Norton, 2000, p.5). According to her, an individual's identity is "constituted in and through language" (Norton, 2013, p.4) and constructed "on the basis of the socially given, and the individually struggled-for" (Norton \& Toohey, 2011, p.420). Norton noticed that investment and power were closely connected to one's identity. As she put it, "an investment in the target language is also an investment in a learner's own identity" (Norton, 2000, p.11), and "relations of power can serve to enable or constrain the range of identities that language learners can negotiate in their classrooms and communities" (Norton, 2013, p.49). Furthermore, Hall (1997, p.226) believed that identity is "not an essence, but a positioning" in particular historical and cultural environments. Norton (2013) also claimed that identity positioning is multiple and shifting; as learners situate themselves in diverse social interactions and learning practices, the educator must explore which identity positions motivate or hinder their learning practices.

\subsection{The Theory of Communities of Practice (CoP)}

In Lave and Wenger's work on CoPs (Lave \& Wenger, 1991; Wenger, 1998), they displayed the pervasiveness of CoPs, such as families, institutions, churches, and schools. Wenger stated that learning was "part of our participation in our communities and organizations" (Wenger, 1998, p.8). He developed the terms participation and non-participation, peripherality, and marginality, and illustrated the interwoven relationships among them to describe learners' learning in communities. Participation reflects an active process of learners' social experience and identity construction in the practices of communities (Wenger, 1998). Peripherality means "some degree of 
non-participation is necessary to enable a kind of participation that is less than full" (Wenger, 1998, p.165), whereas marginality is "a form of non-participation prevents full participation" (Wenger, 1998, p.166). They distinguished these terms by learners' different levels of engagement in the learning process, which could not be separable from exploring learners' investment (Pavlenko \& Lantolf, 2000).

To summarize, in these four theories, investment is the research topic and is undertaken as the main theoretical framework of the current study; CoPs provide the context and a lens (forms of participation) through which to observe students' class investment; and power and identity positioning are presented as potential factors that affect students' investment. Figure 1 displays the main usages and relationships among these four theoretical terms in the present study.

\section{Literature Review}

Norton's construct of investment has received considerable attention in the field of applied linguistics and language education (e.g., Duff, 2002; Haneda, 2005; McKay \& Wong, 1996; Potowski, 2004). For example, in Mckay and Wong's investigation of four basic English skills of Chinese adolescent immigrant students in the United States, they claimed that specific needs, desires, and negotiations of learners "must be regarded as determining their investment in learning the target language" (Mckay \& Wong, 1996, p.603). Duff (2002) in her classroom-based study of ESL students in a Canadian multilingual secondary

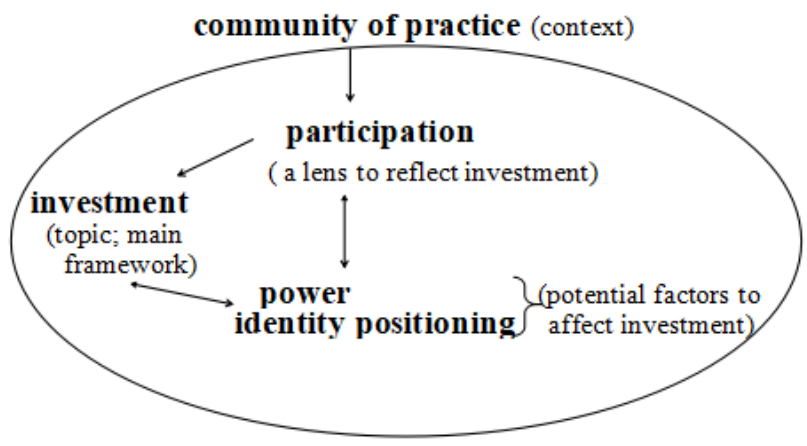

[Figure 1] the main usages and relationships of the four theoretical terms school, revealed that the contradictions, tensions, and unequal relations of power between non-native students and native students affected non-native learners' investments in classroom interactions. In a Spanish/English dual immersion classroom in Chicago, Potowski (2004) investigated students' attitudes, as well as identity positioning and goals teachers and students in the program and found them to be relevant to students' investment. Haneda (2005), through her case studies of two contrastive learners in a JFL (Japanese as a Foreign Language) advanced course at a university in Canada, reflected that learners' differential investment was greatly influenced by their respective life trajectories, attitudes toward learning, and multimembership in differing communities.

In addition, researches on learners' participation and power relations in their communities are also related to and benefit the study of investment. For example, Toohey's (1996) research of young ESL learners in Kindergarten class revealed the existence of various communities within the class, and analyzed the conditions determining children's participation, such as, identities, social practices and resources and power relations. Morita (2004), in the study of six Japanese ESL students in a Canadian university, discussed the challenges and power relations that students met in identity construction and participation in classroom communities. In the abovementioned studies, it commonly discovered that a learner's investment was affected by multiple factors, ranging from individual features to their relations in specific communities. Following such research, the present study explores student participants' individual differences and forms of participation in different class community groups. In doing so, it examines the potential factors affecting their investment in an English Literature class.

\section{Research Methods}

The study was grounded in an ethnographic approach, which focuses on a small number of cases to create a 
cultural analysis and interpretation of people's behaviors in particular settings (Heigham \& Croker, 2009), and has been widely used in educational researches (eg., Erickson, 1982; Potowski, 2004). In the present study, the ethnographic approach contributed to solicit a group of ethnically mixed students' own description and interpretation of their classroom English learning experiences and provide insights on motivating class investment in non-Western educational settings.

\subsection{Setting}

The research setting was in an English Literature class offered by the English department of a Korean public university. The researchers obtained permission from the instructor and students to observe their class to collect the following data. This was a mandatory course offered to English major students. There were a total of 37 students, and 28 of them were Korean in addition to nine international students. The students were a mixture of freshmen, sophomores, juniors, and seniors. The instructor was a white male native English speaker from Canada. He had been working in Korea for about 15 years and was welcomed by most students because his teaching style differed to that of Korean instructors (e.g., data based on student interviews, Adam, Oct. 24, 2019; Hannah, Oct. 18, 2019; Joy, Nov. 15 \& 21, 2019).

At the time of the study, the course covered two modernist American novels, The Old man and the Sea by Ernest Hemingway and As I Lay Dying by William Faulkner, during the whole semester. The class was offered on Wednesdays (one hour) and Fridays (two hours) every week in the form of whole class and small group discussions, which were guided by open questions for each section of the given novel. Students were required to finish reading given chapters of the novels every week, and write reading journals of their reflections on the theme. They were also asked to present cultural and historical background for each section in advance, which were submitted as part of their grading. Through in-class discussions and pre-class reading and writing assignments, students' language and academic practices were both covered, which benefited them to gradually achieve the objectives of the English Literature course. Tables 1 and 2 below provide specific information about the course schedule and evaluation criteria, respectively.

\subsection{Participants}

Focal participants of the study were selected through purposeful sampling, which aims to "select informationrich cases whose study will illuminate the questions under study" (Patton, 2002, p.46). After several class observations, the researchers noticed four students with different nationalities and class performances. During the breaks of the fourth and fifth class observations, the researchers talked with each of them, involving a self-introduction, the aim of the study, a request for personal interviews,

〈Table 1〉 Course Shedule

\begin{tabular}{c|c|c|c} 
Course & Class day & Class time & Course assignments \\
The Modernist American novel & Wednesday & $10-11$ A.M & novel-reading; class discussion; reading journals \\
\hline The Modernist American novel & Friday & $9-11$ A.M & novel-reading; class discussion; reading journals \\
\hline
\end{tabular}

$\langle$ Table 2〉 Course evaluation criteria

\begin{tabular}{c|c} 
Evaluation criteria & Percentage (out of 100\%) \\
participation \& discussion & $20 \%$ \\
\hline reading journals & $20 \%$ \\
\hline mid-term exam (written test) & $30 \%$ \\
\hline final exam (written test) & $30 \%$ \\
\hline
\end{tabular}


and the scope of interview questions. They finally all agreed to participate in the study without asking for any compensation. Among them, Hannah was from Turkey, Caro was from China, and both Joy and Adam were local Korean students. The reasons for selecting them were as follows:

First, the four participants differed in ethnic and cultural backgrounds, which helped the study cover both foreign and domestic students in the class. The participants of ethnically mixed background stimulated the researchers to explore students' investment based on their differences in culture and life trajectory. Second, their cultural as well educational background also informed differences in English language competence, which inspired the researchers to explore the influence of their language competence and personal desires for the course on their class investment. Third, despite the participants' multicultural background, they represented two forms of participation in the class, which inspired the researchers to explore their power relations and identity positioning in different classroom community groups, which are closely related to their class investment.

During the first interview session, the researchers gathered detailed background information of the four participants, including their nationality, age, marital status, major, grades, English learning conditions, as well as their previous working experience and plans for future jobs. These rich information helped the researchers to better understand the participants and their class performances, which were sorted out and listed in the Table 3 according to the relevance to the topic of the present study.

\subsection{Data Collection and Analysis}

\subsubsection{Data collection}

The study was conducted over four months altogether with two phases; the first phase was from October to December 2019, and the second phase was from March to April 2020. During the first phase, the researchers went to the literature class about two times a week, for a total of 13 times and nearly 28 hours. After choosing the participants, the researchers interviewed them approximately five to eight times, respectively, through email, face-to-face meetings, and WeChat and Kakao Talk applications. During the second phase, the researchers continued to interview participants and share the data analysis with them to complete member checking, confirm the validity of data interpretation by the researchers, and clarify some

〈Table 3〉 Participant background information

\begin{tabular}{|c|c|c|c|c|}
\hline Name & Hannah & Caro & Joy & Adam \\
\hline Gender & female & female & female & male \\
\hline Age & 27 & 23 & 22 & 22 \\
\hline Nationality & Turkey & China & Korea & Korea \\
\hline Marriage & Yes & No & No & No \\
\hline Major & English & English & English & English \\
\hline $\begin{array}{l}\text { Length of English } \\
\text { Learning (years) }\end{array}$ & 22 & 8 & 13 & 14 \\
\hline Grade & $1^{\text {st }}$ year, $2^{\text {nd }}$ semester & $1^{\text {st }}$ year, $1^{\text {st }}$ semester & $3^{\text {rd }}$ year, $2^{\text {nd }}$ semester & $3^{\text {rd }}$ year, $1^{\text {st }}$ semester \\
\hline $\begin{array}{l}\text { Strengths in English } \\
\text { (self evaluation) }\end{array}$ & reading, listening, speaking & reading, writing & reading, writing & reading, writing, listening \\
\hline $\begin{array}{l}\text { Weaknesses/Desires of } \\
\text { improvement in English } \\
\text { (self evaluation) }\end{array}$ & grammar, writing & speaking & speaking, listening & speaking \\
\hline $\begin{array}{l}\text { Previous working } \\
\text { Experience }\end{array}$ & $\begin{array}{l}\text { Korean interpreter } \\
\text { (full-time) }\end{array}$ & $\begin{array}{l}\text { Intemational hotel staff } \\
\text { (full-time) }\end{array}$ & $\begin{array}{l}\text { Market staff } \\
\text { (part-time) }\end{array}$ & $\begin{array}{l}\text { English teacher of a private } \\
\text { institution (part-time) }\end{array}$ \\
\hline Ideal future Job & English teacher/interpreter & $\begin{array}{l}\text { Employee offoreign } \\
\text { company/translator }\end{array}$ & Public official & $\begin{array}{l}\text { English teacher in local } \\
\text { junior or high school }\end{array}$ \\
\hline
\end{tabular}


unclear points. The data for the study mainly included field notes from class observations, notes and transcribes of semi-structured and informal interviews, and course documents such as the course syllabus.

\section{(1) Field notes of class observation}

During class observations, the researchers jotted down the following information: the layout of the classroom, distribution of students, appearance of the instructor, categories of students based on gender and nationality, attendance of each class, task and teaching procedure of each class, and students' performance each time. Moreover, the researchers jotted down detailed performance notes of the four participants in the whole class and small group discussions. Based on the notes, the researchers attempted to avoid an impressionistic summary and subjective evaluation (Emerson, Fretz \& Shaw, 2011), and produced the current field notes based on class observation.

\section{(2) Semi-structured interviews}

After choosing the participants, the researchers began to interview them through emailed interview questions, face-to-face meetings, and the WeChat or Kakao Talk applications. First, since the first interview was planned just before participants' mid-term exam, to solve the time conflicts, the researchers chose to email a file with 12 open questions (see Appendix 1) to them and collected the basic information of their English learning experience. Then, after the mid-term, the researchers invited them individually to have face-to-face interviews in a quiet restaurant or coffee shop based on the researchers' prepared questions (see Appendix 2); sometimes the interviews were extended to include follow-up questions based on student responses. These semi-structured interviews, together with some informal talks through face-to-face meetings, helped the researchers and participants establish a close and reliable relationship, and benefited the researchers in obtaining participants' explanations of their performance in the English Literature class. Furthermore, the researchers frequently talked with them over WeChat and Kakao Talk, which helped obtain their immediate and routine learning information. All of the interviews were audio-recorded and transcribed for data analysis.

\section{(3) Course documents}

The researchers collected the course syllabus and guidelines for learning literature, which covered the goal, plan, content, requirements, and tasks of the course in detail. These materials provided the basic information of the course design, which were especially significant to the study when the researchers investigated students' (non) participation in the class.

\subsubsection{Data analysis}

The research topic was constructed through a comparative method (Glaser \& Strauss, 1967). Initially, the researchers consulted field notes of each class observation and noticed the salient feature of the students' performance in this English Literature class - mostly passive participation and silence. Interview transcriptions were then examined to find themes from students' responses and to make clear reasons from the view of students' individual differences. Thereafter, the researchers checked the course syllabus and guidelines and compared the course goal with students' personal desires for the course. Finally, the researchers compared field notes of class observations and interview transcriptions to analyze their participation in different classroom groups. After completing the data analysis, the researchers shared and discussed the data analysis with participants. Through member checking, participants confirmed the validity of the researchers' interpretation and analysis of the data, and simultaneously clarified some unclear points in the analysis. Finally, the compiled information based on the data formed the foundation for this ethnographic study. 


\section{Findings}

In the investigation, all four participants expressed their high motivation to learn English (e.g., data based on student interviews, Hannah, Nov. 25, 2019; Joy, Nov. 21, 2019; Caro, Nov. 10, 2019). Yet, there was a gap between students' initial motivation and their class investment based on the researchers' class observations. Through participants' interviews, course documents, and observations of the participants' participation in different classroom community groups, the researchers discovered that the factors strongly affecting students' investment in the class were as follows: students' individual differences, the disjuncture between the course goal and the personal desires of students, and the inequitable power relations and differential identity positioning in classroom groups.

\subsection{Analysis of Students' Individual Differences}

During class observations, one student, Hannah displayed the most active performance in the class, whereas Caro, Joy, and Adam were comparatively inactive, silent, and appeared unengaged. Through the researchers' interactions and interviews with them, it appeared that their English speaking competence, personalities influenced by different cultures (see Table 3. nationality), and the trajectory of language acquisition constituted the main features of their individual differences, which informed their class investment

For example, Hannah was more confident, straightforward, and appeared to hold a positive attitude in all class discussion activities. In the interviews, she attributed her performance to her good command of English speaking competence and her confidence. Other Asian students also reflected that the active performance of some international students, such as Hannah, was because of their confidence influenced by European culture, which was expressed as follows:

"I already know how to speak English...I'm confident...They (other students) don't influence my speaking performance" (Hannah's interview, Nov. 25, 2019).

"They (international students except Chinese and Korean) don't care about other people and answer freely. They even don't [sic] embarrassed when they give the wrong answers. I think the reason is the culture of education and students mind" (Joy’s interview, Mar. 13, 2020).

Moreover, Hannah reflected that before coming to Korea, she had graduated from a Turkish university majoring in the Korean language, and worked in some companies as a Korean interpreter to live by herself. After getting married, she followed her Korean husband to Korea, where she continued her study majoring in the English language, because her previous working experience made her realize that English competence would provide her with more opportunities for job-hunting in the future. She expressed her eagerness to maintain a self-made and independent foreign female image in Korean society. As she mentioned,

"I want to find a job quickly...I'm trying to survive in a country which is so far from where I was born. I have to work hard for it. I like to be active in society. I think to be at home and to except (expect) for somebody to bring you money, food etc. makes women a second-class citizen. I have respect to [sic] myself' (Hannah's interview, Nov. 25, 2019)

Thus, Hannah's English language competence, personality, and the trajectory of language acquisition positioned her as a confident foreign student and a housewife with expectations of independence. This identity positioning encouraged her high investment, which would bring her the material and symbolic resources she expected for $-\mathrm{a}$ job for survival and independence as well as respect in Korean society.

Similarly, the other three participants attributed their 
inactive participation to their limited English speaking competence or personal characteristics influenced by Asian culture. In the interviews, they offered the following reflections:

"I feel nervous and uncomfortable when I speak with strangers because I worried [sic] too much about my mistake or English ability" (Joy’s interview, Nov. 14, 2019).

"Korean education culture is usually one-sided. Most classes were [sic] taught by teachers... students are awkward to speak [sic] their opinion. Also, Koreans are too conscious of people around them” (Joy’s interview, Mar. 9, 2020).

"There are many classmates who can speak good English...(Silence is) a tradition in all (Korean) classes...I'm introverted." (Adam's interview, Nov. 15, 2019).

"If they (international students except for Chinese) speak up [sic] wrong answers during the class, it's not embarrassing. But in Korea, things are opposite. So, students are not willing to express their thoughts or feelings during the course" (Adam's interview, Mar. 16, 2020).

"I admire students with good language competence... my inactive [sic] in the class is mainly because of limited speaking competence" (Caro's interview, Mar. 9, 2020).

Joy and Adam stressed their limitation in English speaking competence: the cautious nature of Korean people, and their worries and anxieties when speaking in the class. Caro explained that her performance was mainly hindered by her English speaking competence; she expressed her admiration for students like Hannah and desired to perform like them in the class. Therefore, three of them positioned themselves as poor English speakers or what Caro noted as "traditional Asian students," accustomed to passive acceptance of knowledge and an inactive form of participation, which made their investment limited (part of Caro's interview, Mar, 2020)

In sum, the researchers observed that the differences between the four participants' were mainly displayed in their English speaking competence, personalities influenced by their dominant cultures, and the trajectory of language acquisition, which produced different identity positioning among them and impacted their class investment.

\subsection{Analysis of the Disjuncture between the Course Goal and Students' Desires}

When comparing field notes of class observations and participants' interviews with the course syllabus, the researchers noticed that the goal of the course diverged from some students' expectations of their ideal English class. This English Literature course generally highlighted academic knowledge, aiming to help students realize the basic elements of the literary works and share their understanding of and inspiration from them from different perspectives. The English language mainly functioned as a communicative tool for students to share ideas in the class. When students failed to interact well with each other in English, the instructor allowed - though did not encourage - the use of their first language in group discussions. However, among the four participants, three declared their current desire for the course was to improve their speaking ability (see Table 3. weaknesses/desires of improvement) because there are few opportunities outside the class for them to practice English in Korea. This disjuncture between the goal of the course and the personal desire of the students caused some students to hold ambivalent attitudes toward the English Literature class, which were reflected as follows.

Initially, Caro, Joy, and Adam explained their current desires for basic English language skills, especially speaking competence, to pass the related English competence test due to the consideration of future jobs; however, the content of the Literature class showed little connection with such needs. As Joy stated,

"I think English that I learn at school is not 
directly helpful...there is a big difference between English for exam and English for learning...my test (TOEIC) is not related (with things learned from the Literature class)" (Joy’s interview, Nov. 21, 2019).

The interesting point here was why some students had to take this literature class, especially when they realized the misplacement between the goal of the course and their personal desires for English learning. They responded that in their department, most instructors' courses were offered in Korean, which made the foreign instructors' courses more popular. They assumed that the foreign instructor could at least provide more opportunities for them to practice English (e.g., notes of interviews, Caro, Nov. 10, 2019; Joy, Nov. 11, 2019). Thus, even though the goal of the course did not match their future desires for English learning well, they still believed in the value of learning literature and, in particular, expressed their positive impression towards the instructor:

Caro mentioned she liked this class because the professor was so nice and tolerant, and allowed the diverse ideas and voices expressed in the class (notes of Caro's interview, original Chinese, Nov.10, 2019).

"I like A's (the instructor) style. It's because he respects and accepts the student personal opinions even these are different with his opinion..." (Joy's interview, Nov. 21, 2019).

On the one hand, they expressed the disjuncture between the goal of the course and their current desires for English learning, whereas on the other hand, they showed their acceptance of the course and instructor. Their ambivalent attitude toward the course caused their limited class investment. For example, although Caro and Joy mentioned that they attempted to show collaboration during class activities, complete all reading assignments on time, and even manage to figure out the content of a novel with the help of the translated version of their first language, they still positioned themselves as inactive and inexperienced novice learners in the class-listening, watching, and failure to openly share opinions before the whole class and gain peer feedback on activities.

Compared with Caro and Joy, Adam's class performance was more passive. The researchers found that he mostly remained silent in most classroom activities. When he expressed his admiration for the instructor, he highlighted that the instructor would "give good grade...few homeworks [sic]" (Adam's interview, Nov. 21, 2019). During class observations, he was often late for class, sometimes even missing one hour (two hours on Friday class) several times. He always sat in the back row, frequently used his phone in classes, and sometimes briefly left the classroom during class hours. He positioned himself as a passive attendee, taking on an alienated, uninvolved attitude of participation only for politeness and grades. By contrast, Hannah was the only one whose needs for this course matched its goal. She expressed her favor for the instructor too, but that was another merit of the course. She clearly expressed that "literature is better than speaking English...I love literature, It's more fun for me; I like the content" (Hannah's interview, Nov. 22, 2019). Because of her desire for more English-based academic knowledge, she exhibited a constant positive attitude and active participation in different group activities of each class, which pointed to her strong investment in the class.

In sum, the cases of the four participants indicated that the relationship between the goal of the course and personal desires of the students for the course affected students' class investment. When the goal of the course aligned with students' desires, it helped students maintain a positive attitude and motivation for high investment in the course. However, when the goal of the course was not aligned with the students' professional desires, it triggered their ambivalent attitude towards the class, thus, hindering their class investment. 


\subsection{Analysis of Students' Power Relations and Identity Positioning Within Class}

\subsubsection{Class Community Groups}

Following Toohey's (1996) finding of the existence of various communities within a class, different class community groups were also observed to coexist within this Literature class: the official classroom group, which included the instructor and all the students, and seven mini-groups, each of which was formed by four students with a common first language, similar background, or close personal relations. Through observing different forms of activity participation of the four participants in the official classroom group and mini-groups, the researchers analyzed how the power relation was distributed among students, how students positioned themselves, and how power relations and identity positioning affected their class investment.

\subsubsection{Power relations and identity positioning in the official classroom group}

Based on class observations and interviews, students could be divided into two types based on their English speaking competence: one included the Canadian instructor, some non-Asian students, and other Korean students with overseas experiences, all of whom had a good command of speaking competence; the other type was the rest of the students, who had difficulty in expressing themselves fluently, clearly, and naturally. Since the instructor encouraged that all discussion tasks to be fulfilled in English, the instructor and those who could speak fluent English represented old-timers in this English-based official classroom group, and the remaining students were positioned as newcomers. It was observed that the old-timers and newcomers displayed different forms of activity participation. Based on Wenger's (1998, p.167) division of participation, the four participants displayed two specific forms of participation in this official classroom group: full participation and peripheral participation, as shown in Figure 2:
Based on our data, Hannah's full participation was observable because of her fluent speaking competence, confident personality, and satisfaction with the course design, which were discussed in Section 6.1 and 6.2, and also because of her consistent self-discipline, devotion, and motivation in learning English, which were related in the following interview excerpts:

"I read hundreds of pages in literary English...It obviously helps to develop my English" (Hannah's interview, Oct. 18, 2019).

"I intentionally try to participate in the class...If I don't participate in the class, I feel like I can't learn everything” (Hannah's interview, Nov. 22, 2019).

"My goals are motivating me. I have to work hard for it" (Hannah's interview, Nov. 25, 2019).

In addition, during class observations, Hannah attended almost all the classes except for one on November 23. She was also never late for class, and always sat in the first row near the instructor. In the overall discussion offered by the official classroom group, she took the floor to speak often when responding to the instructor's questions and during class participation. Hannah's competence and devotion for gaining "the right to speak" in the class clarified her positioning as a somewhat authoritative old-timer and leader in this official classroom group. This further confirmed her motivation and thus investment in

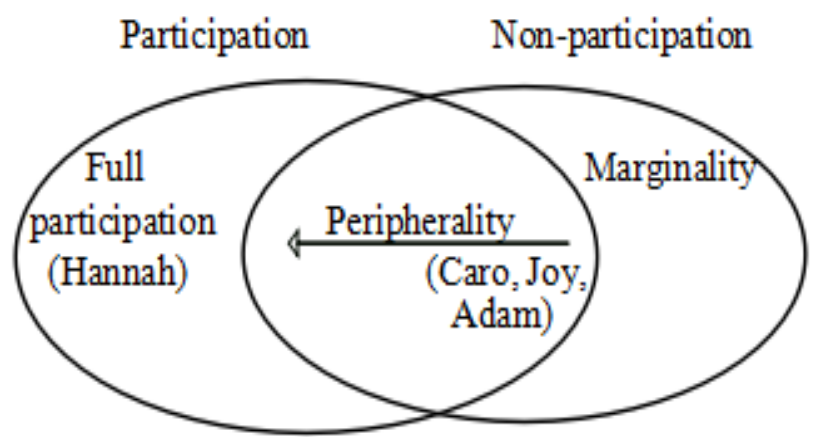

[Figure 2] Specific forms of participants' a ctivity participation in the official classroom group 
the class.

By contrast, the other three participants emphasized their limited English language competence (see Section 6.1) and a lack of literary knowledge; for example,

"I don't know about American period background and Christian symbolism very well. So sometimes, I'm given some discussions that I really don't know. There is much more I don't know and feel apart from the class..." (Joy’s interview, Nov. 21, 2019).

"I'm not sure what can I say. I have a hard time understanding the background of the text (Adam's interview, Dec, 10, 2019).

Because of such limited knowledge, Joy positioned herself as inferior to those who could speak fluently and confidently, confining their identities in this official group only as inexperienced, powerless, and inactive newcomers. Then, in the official group discussion, silence became the tag of their activity participation. According to Duff (2002), silence may be perceived as a means to protect their self-dignity and avoid mockery and contempt from other students. However, in this study, silence caused a barrier during class participation, which challenged the power of their voice, restrained their participation within the peripheral bounds, and finally threatened their class investment.

In sum, in this official classroom group, the more "right to speak" Hannah obtained, the more positive an identity would be constructed, and the more investment would be motivated; conversely, her high investment would gain recognition from her instructor and peers, and enhance her language competence and academic knowledge. By contrast, in the cases of the other three participants, their class investment was mainly hindered by them lacking the "right to speak" and their inactive and unconfident identity positioning.

\subsubsection{Shifting identity positioning in mini-groups}

Most small groups were formed by members who kept close relationships or shared the same first language or background. The former unequal power relations were reduced to the minimal level in such comparatively free safety zones. Consequently, in these comparatively relaxed mini-groups, slight changes were noted in participants' participation, as displayed in Figure 3.

In Figure 3, Hannah is shown to still reflect full participation, which was supported by her consistent devotion, cooperation, and especially high responsibility in her mini-group. She claimed that,

"I am trying to be active, I try to do something, if everybody is silence, we can't reach anything.

Nothing get [sic] advance. Someone has to do something” (Hannah's interview, Nov. 22, 2019).

Hannah regarded the group tasks as her own responsibility, and positively took the role of "someone" who should make contributions in accomplishing the group tasks. This confirmed her consistent identity positioning as a positive and responsible old-timer and promising master-to-be in different groups.

Meanwhile, some changes could be found in Caro and Joy's performance in their mini-groups. They broke their silence and became more talkative in group discussions, positioning themselves as more active participants and sometimes even masters-to-be among group members. As

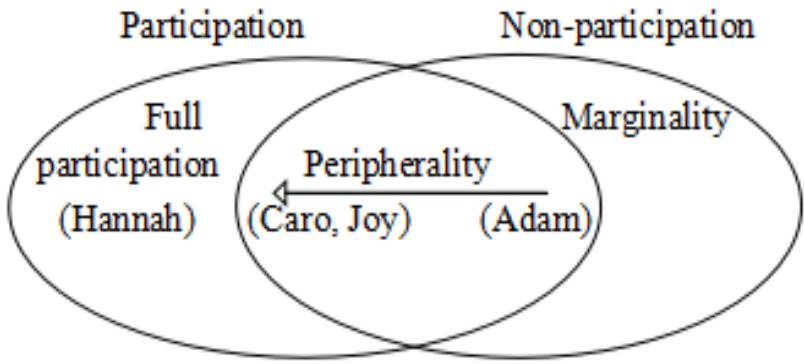

[Figure 3] The shifting forms of a ctivity participation of participants in mini-groups 
for Caro, when she was not familiar with the content, she would ask her peers' related questions to collect information, and cooperate in the group discussion; when she was familiar with the content, she would occasionally lead the discussion (field notes of class observation, Oct. 16; Nov. 20). Joy invested even more than Caro in her group. She responded, "When I do group work with my friends, I always lead the group...I like to speak English or to lead the group in a comfortable environment" (Joy's interview, Nov. 14, 2019). When the instructor came close to them, she would actively ask for assistance. These performances in small groups helped them obtain some access to full participation, which contrasts from their peripheral position seen the whole classroom.

However, Caro and Joy used their first language rather than English in their mini-groups to communicate. Although this was permitted by the instructor, English was strongly encouraged in this class (notes of Joy's interview, Nov. 15, 2019). The use of their first language might contribute to maintaining their current intimate relationship among members and avoid the risk of being excluded by peers, while it constituted a barrier preventing them from full participation. This reflected their identity positioning as struggling students rather than active participant learners. Therefore, while Caro and Joy displayed moments of active and improved participation in mini-groups, the researchers held that these instances pointed to progressing as full participants in their local small group communities, but it was difficult to perceive them as fully claiming pro-active participation in the class as a whole. Nor was it sufficient to claim that they had a strong investment on the class.

Compared with the other three participants, Adam invested the least in mini-groups. He put himself in the position of an ambivalent and passive attendee in any group. However, he did not retreat from learning, because he finished the reading tasks and writing journals for each section and passed the course evaluation. His participation should still be in the range of peripherality rather than marginality. The researchers held that the possible reason for his willingness to remain in peripheral participation was that it demanded less time-spending, effort, devotion, and responsibility compared with full participation. More importantly, it did not produce a distinct gap with others in their final course grades, which happened to be an important motivation for Adam to attend the course, as reflected in his interview when he said "I can get good grades...and there are few homeworks [sic], so I want to come to class" (Adam's interview, Nov. 21, 2019).

To summarize, in mini-groups, when the inequitable power relations among students was reduced to a minimal extent, their English speaking competence and identity positioning became salient to affect their class investment. Even though Caro and Joy made efforts to win the power to speak and managed to participate actively as cooperative learners, their investment was still limited from the view of their whole class performances. As for Adam, the researchers held that some external drive might be required; for example, he thrived in the class when specific tasks and strict evaluation standards from the instructor were clearly set.

\section{Discussion}

Among the four focal participants, they all expressed high motivation in learning English. However, their individual differences, personal desires, inequitable power relations, and differential identity positioning reflected through their distinct forms of participation in class, noticeably affected their class investment. For example, Hannah's high investment was motivated by her confident and active personalities, unique trajectory of language acquisition, approval of the course design, competence to speak, and multiple identity positioning-an independence-expecting housewife in society and an authoritative, responsible, and promising old-timer in the class. This case revealed Hannah's individual factors related to her class investment, as well as mirrored Haneda's (2005) view that investing in language learning is especially connected with students' life histories 
and identity positioning in communities.

Caro and Joy realized their weaknesses in language competence and personality barriers, and tried to make up the gap between their desires and the course requirements to adapt to the class progression. They also realized to gain full participation in their current $\mathrm{CoP}$ they needed to overcome their embarrassment and anxiety and learn from the old-timers and the whole classroom. However, in reality, their silent performance in the official classroom group estranged them from other members, confined their competence to speak and hindered their investment. This view was echoed by Duff's (2002) observation that newcomers' silence in class would attract disdain from old-timers, produce aloof and unequal relations, and be regarded as reluctance in participation. In addition, their language choices between English and their first language in different classroom groups implied their limited language competence. It also informed their struggling identities, shifting from inactive and powerless newcomers in the classroom group to tentative active learners in mini-groups. Similarly, Potowski (2004) found that students' selective use of language in the classroom were related to their attitudes and identity positioning. Thus, their silence and use of first language in class made it relatively difficult to be accepted as full members of the official classroom community by the old-timer. For example, in Adam's position as a passive peripheral attendee in any group supported Norton and McKinney's (2011, p.76) view that a motivated learner "could be excluded from the language practices of a classroom, and in time positioned as a poor or unmotivated language learner". The researchers found that although Adam desired to be an English teacher in the future (see Table 3) through his investment in English learning, he did not discipline himself as a diligent student in the class. He positioned himself in the peripheral of the class community just enough to pass the course.

Furthermore, through comparing the distinct forms of participation of the four participants, the researchers found that students' personal desires for the course and inequitable power relations in class also played vital roles in class investment, which was respectively aligned with the views of Mckay and Wong (1996), Toohey (1996) and Morita (2004). Referencing the abovementioned studies, the current study discussed factors that that affected a group of ethnically mixed students' class investment, especially in non-Western settings.

\section{Conclusion and Implications}

Through the cases of four participants, the findings indicate that in English-based classes where students show diverse backgrounds and language competence, it is important that instructors scaffold and motivate students' investment, especially in non-Western countries. First, it is essential for the instructor to announce the goal, requirements, and teaching methods of the course clearly and comprehensively in advance. In an English-based academic class (e.g., the Literature class in this study), it is better for the instructor to strictly enforce the Englishonly rule in the class, and provide more language practice. As Potowski (2004) noted, clear classroom interactional routines and instructors' expectations for language use greatly influenced students' language choices. In the teaching process, the instructor must help students take account of students' individual differences, mediate class atmosphere, develop intercultural awareness, and be more aware of marginalizing students, especially caused by inequitable power relations among students. Moreover, the researchers believe that strict course evaluation criteria might be helpful for some individuals, particularly passive learners, to motivate their class participation. Finally, the instructor may help students self-examine themselves, and allow space for marginalized student to strive for their right to speak to participate actively.

In terms of limitations of this study, the present study only lasted four months, which made the depth and breadth of the findings limited. Furthermore, the study only focused on the students' investment in the class, and their investment after the class in English learning 
would be included in a subsequent study. Finally, the researchers will continue to collect data from focal participants and the instructor to further triangulate the validity of the collected data and obtain further insights from the perspective of the instructor on this topic.

\section{References}

Bourdieu, P.(1977). "The economics of linguistic exchanges", Social Science Information 16(6), 645-668.

Duff, P.(2002). "The discursive co-construction of knowledge, identity, and difference: An ethnography of communication in the high school mainstream", Applied Linguistics 23(3), 289-322.

Emerson, R. M., Fretz. R. I., \& Shaw, L. L.(2011). Writing Ethnographic Fieldnotes (2nd ed.), Chicago: The University of Chicago Press.

Erickson, F.(1982). Audio-visual documentation of everyday life in schools: A handbook of methods and resources, East Lansing, MI: Institute for Research on Teaching, Michigan State University.

Foucault, M.(1980). Power/Knowledge: Selected Interviews and Other Writings, 1972-1977 (C. Gordon, trans.), New York: Pantheon Books.

Glaser, B. G., \& Strauss, A. L.(1967). The discovery of grounded theory: strategies for qualitative research, Chicago: Aldine.

Hall, S.(1997). Representation: Cultural Representations and Signifying Practices, London: Sage Publications.

Haneda, M.(2005). "Investing in foreign-language writing: A study of two multicultural learners", Journal of Language, Identity, and Education 4(4), 269-290.

Heigham, J., \& Croker, R. A.(2009). Qualitative research in applied linguistics: A practical introduction, London: Palgrave Macmillan.

Lave, J., \& Wenger, E.(1991). Situated learning: Legitimate peripheral participation, New York: Cambridge University Press.
McKay, S. L., \& Wong, S. C.(1996). "Multiple discourses, multiple identities: investment and agency in second language learning among Chinese adolescent immigrant students", Harvard Educational Review 66(3), 577-608.

Morita, N.(2004). "Negotiating participation and identity in second language academic communities", TESOL Quarterly 38(4), 573-603.

Norton, B.(1995). "Social identity, investment, and language learning", TESOL Quarterly 29(1), 9-31.

Norton, B.(2000). Identity and language learning: Gender, ethnicity, and educational change, Edinburgh Gate: Pearson Education.

Norton, B.(2010a). "Identity, literacy, and English-language teaching", TESL Canada Journal 28(1), 1-13.

Norton, B.(2010b). "Language and identity", In N. H. Horberger \& S. L. Makay (Eds.), Sociolinguistics and Language Education (pp. 349-364), Bristol, UK: Multilingual Matters.

Norton, B.(2013). Identity and Language Learning: Extending the Conversation (2nd ed.), Bristol, UK: Multilingual Matters.

Norton, B., \& McKinney, C.(2011). "An identity approach to second language acquisition”, In D. Atkinson (Ed.), Alternative approaches to second language acquisition (pp. 73-94), New York: Routledge.

Norton, B., \& Toohey, K.(2011). "Identity, language learning, and social change", Language Teaching 44(4), 412-446.

Patton, M. Q.(2002). Qualitative research \& evaluation methods (3rd ed.), A Thousand Oaks: Sage Publications.

Pavlenko, A., \& Lantolf, J.(2000). "Second language learning as participation and the (re) construction of selves", In J. Lantolf (Ed.), Sociocultural Theory and Second Language Learning (pp.155-178), Oxford: Oxford University Press.

Potowski, K.(2004). "Student Spanish use and investment in a dual immersion classroom: implications for second language acquisition and heritage language maintenance", The Modern Language Journal 88(4), 75-101.

Toohey, K.(1996). "Learning English as a second language in kindergarten: A community of practice perspective", Canadian Modern Language Review 52(4), 549-576.

Wenger, E.(1998). Communities of Practice: Learning, Meaning and Identity, Cambridge, England: Cambridge University Press. 


\section{Appendix 1 Sample Interview Questions}

Oct. $18^{\text {th }} / 2019$, paper interview \#1

All research feedback will be analyzed in pseudonyms.

1. What is your age?

2. Where is your hometown?

3. How long have you been learning English?

4. Please briefly introduce your junior middle school and high school English class.

(1) How many students are there in your class: Junior: High:

(2) Which aspects do you practice more in your class comparatively: speaking reading listening writing

(3) Do you have an extra speaking class for practicing English? $\mathrm{Y} N$

(4) Does the English exam always include four aspects, speaking, reading, listening, and writing?

Or which aspects does the exam mostly focus on?

5. Have you ever accepted other private English training courses except for formal middle or high school English classes in your country or hometown before entering our university?

6. Do you like learning English? Why do you choose English as your major? Is it your own choice or someone's advice?

7. What are your advantages and limitations of your English ability? (Speaking, writing, reading, listening) Which aspects do you want to enhance?

8. Do you like this literature class? Do you think reading original novels can help you improve your English level?

9. After class, how do you usually practice or develop your English? For example: reading an English novel, magazine, watching movies, listening to music, chatting with friends in English?

10. Do you think whether the literature class is helpful in your English learning? In what way?

11. Do you like the professor's teaching style? In what aspects? (If not, why?)

12. What is your plan for your future? (To be an English teacher?)

\section{Appendix 2 Sample Interview Questions}

Nov. $10^{\text {th }} / 2019$, face-to-face interview \#2

All research feedback will be analyzed in pseudonyms.

1. Why did you choose to learn English in Korea? How do you feel about learning English in Korea?

2. Please describe your own performance in the current Literature class.

3. Do you prefer to participate in class discussion, answer questions actively, or listen to others' ideas mostly during English class, especially Modern Literature? Why?

4. I found most of you sit in the same seats each class, do you like to sit alone or with your classmates, why? And why do you choose your designated seating?

5. What elements are included in your final score of Literature course? What proportion does each element cover? (Attendance, class performance, mid-term exam, final exam, etc.)

6. Do you have any close friends in your class? What language do you use with your friends during the class discussion? English, Korean, Chinese? Why?

7. Do you have any friends who are native speakers or with whom you need to communicate in English ? How do you contact each other? Does he/she help you to improve your English? If so, how?

8. Have you ever tried to invite your foreign classmates to join in your group discussions? Briefly explain. If not, why?

9. What is your general impression on your classmates' class performance, for example, Korean classmates, Chinese classmates, other foreign classmates? 


\section{한국 대학에서 학생들의 영문학 수업에 대한 Investment(시간 투자)에 영향을 미치는 요소}

김정인', Lixia $\mathrm{Qi}^{2}$

1전북대학교 교수

2전북대학교 박사과정

초록

이 질적 (ethnographic) 연구는 한국 공립 대학의 영문학 수업에 대한 학생들의 investment에 영향을 미치는 잠재적 요인에 대한 탐구이다. 이 연구는 4 개월간 진행되었으며, 4 명의 연구 대상 학생은 개인의 문화적 배경, 영어 능력 및 수업참여 유형의 차이를 고려하여 선정 되었고, 연구 데이터는 수업 관찰, 반 구조화 된 인터뷰 및 수업 자료 (예: 강의 계획서 및 학습 학습 지침)를 통해서 수집되었다. 본 연구는 Lave and Wenger의 실천 공동체 (Community of Practice)이론뿐만 아니라 investment, 권력 관계, 문화적 정체성, 그리고, 공동체 속에 위치 에 대한 노턴 (Norton)의 이론을 바탕으로 참가자의 개인의 문화적 차이, 코스에 대한 개인적 욕구 및 강의실 커뮤니티 참여 형태를 분석했다. 본 연구를 통하여 영문학 수업에 대한 학생들의 investment가 다음과 같은 요인에 의해 영향을 받는 것을 발견했다. 1) 참가자의 개인 문화적 차이, 언어 능력, 자신이 속한 문화에 영향을 받은 개인 성향 그리고 삶의 목적, 2) 수업 목표와 수업에 대한 학생들의 개인적인 욕구 사이의 차이, 3) 교실 공동체에서 불평등 한 권력 관계와 차별적 정체성. 이 연구는 다양한 문화적 배경과 언어 능력을 보이는 학생들이 참여하는 영어 기반 수업에서 학생들에게 수업에 investment 하도록 동기를 부여하는 것이 강사의 중요한 역할 이라고 나타낸다.

주제어: 실천 공동체, 투자, 정체성 포지셔닝, 권력 관계, 영문학 수업 